\title{
Ôsjegy a felhôben
}

\author{
Lehoczky Máté - Busics György
}

DOI: $10.30921 / G K .72 .2020 .3 .2$

Absztrakt: A pontfelhôalapú felmérési technológiák nagy népszerüségnek örvendenek az utóbbi években. Míg a földi lézerszkennelés széles körben elismert, az UAV-platformról végzett légi fotogrammetria és távérzékelés felhasználhatósága gyakran vitatott. A vonatkozó pontossági kérdéseket csak részben lehet megvizsgálni, de a szakembereket ösztönözni kell ezek végrehajtására. Ebben a tanulmányban a nadapi szintezési ôsjegy történelmi helyszínén vizsgáltuk egy „rutinmunka” megbizhatóságát.

Abstract: Point cloud measurement technologies have been extremely popular in recent years. While the quality of ground laser scanning is widely recognised, the surveying usability of aerial photogrammetry and remote sensing, mainly from the UAV platform, is often controversial. The relevant accuracy issues can only be partially investigated, but professionals should be encouraged to carry out them. As part of this document, we examined the reliability of a "routine work" at a historical site in Nadap National Benchmark.

Kulcsszavak: szintezési főalappont, pontfelhő, földi lézerszkennelés, UAV, fotogrammetria Keywords: national benchmark, point cloud, terrestrial laser scanning, UAV, photogrammetry

\section{A helyszín bemutatása, a vizsgálat célja}

A Fejér megyei Nadap község területén, festôi környezetben található az ún. szintezési ôsjegy, az elsô országos szintezési hálózat egyik főalappontja, a hazai magasságmeghatározások viszonyítópontja.

A monarchiabeli elsố, országos szintezési hálózat mérési munkái 1873-ban kezdôdtek. A szintezést katonatisztek végezték, nevezik ezért katonai szintezésnek, illetve hálózatnak is. Azt a szintezési vonalat, amelyból a Nadap pont magasságát levezették, 1873 és 1879 között mérték. Ez a szintezési vonal Triesztból indult

(ahol a Molo Sartorio mareográfján mérték az adriai középvízszintet), és a Trieszt-Budapest vasútvonal mentén, a Balaton és a Velencei tó déli partján haladt. A vonal egyik magassági alappontja (egy furatos tábla) Kápolnásnyék község vasútállomásának épületében volt. Errôl a magassági alappontról szárnyvonallal vezették le egy (ma is látható) furatos tábla magasságát, amelyet a nadapi felhagyott kóbánya sziklafalában állandósítottak. A fóalappont magasságát 1888-ban mérték, amelynek magassága a kiegyenlítés után 173,8385 méternek adódott az adriai alapszinthez viszonyítva. (Busics 2013)

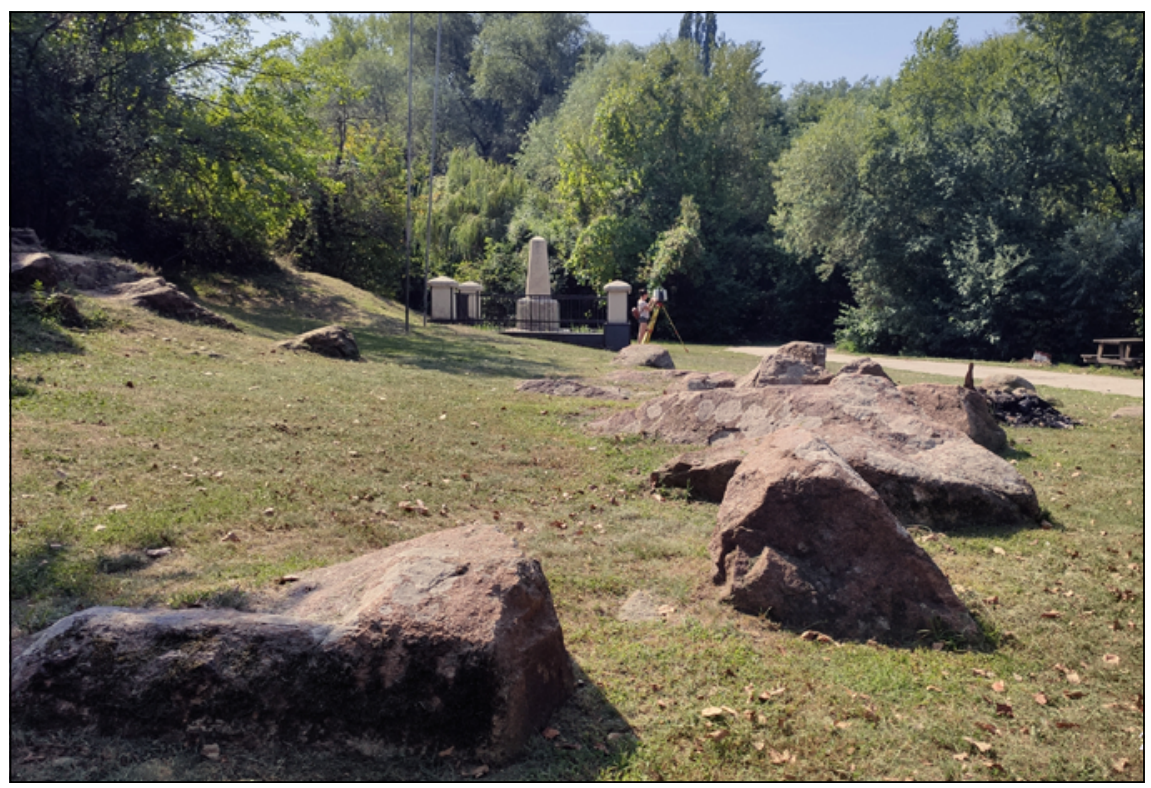

1. ábra. A szintezési ôsjegy környezete
Maga az őspont voltaképpen a Velencei-hegységet alkotó gránit alapkôzetnek egy $20 \times 20 \mathrm{~cm}$ méretú, vízszintesre csiszolt felülete, tehát egy természet adta felület. Azért építettek föléje obeliszket, hogy az idójárás vagy a vandalizmus ellen védve legyen. Az obeliszk alsó része üreges, egyetlen kôtömbból faragták ki (a fagyvédelem miatt), oldalára latin feliratot véstek. A felsô kôtömb 130 $\mathrm{cm}$ magas és az alsó részen elmozdítható, hogy a mérés idején szintezólécet lehessen felállítani a sziklafelületen. Az a tény, hogy több mint másfél évszázada áll az obeliszk, azt igazolja, hogy az egykori szakemberek alkalmas helyszínt és idôtálló pontjelölést találtak; valóban „locus perennis”, azaz „örökös hely”.

A történethez hozzátartozik, hogy 1951-ben az eredeti ponttól mintegy 200 méterre egy újabb fôalappontot létesítettek, amit Nadap II.-nek neveztek el, míg az óspontot Nadap I.-nek. Ez fizikailag három szintezési gombot (pontcsoportot) jelent, amelyeket egy sziklaüregben, fedlapokkal védve állandósítottak, és ôrpontokkal látták el. A szintezési gombok magasságát is az ôspontról vezették le. 1960-ban Magyarországon (a Varsó Szerzôdés tagállamaihoz hasonlóan) megváltoztatták az alapszintet, ekkortól a Balti-tenger kronstadti középvízszintjét kellett elfogadni viszonyítási alapnak. Ebben a balti magassági rendszerben a nadapi ôspont magassága 173,1638 méter. Az 1980-as évektôl 
létesült a legújabb, ma is használatos országos szintezési hálózat, az EOMA (ennek 0000001-0 számú fóalappontja az ôspont). Az EOMA elsôrendû hálózatának kiegyenlítésénél (ami dinamikai magasságok alapján történt) a Nadap II. alappont legfelsố gombjának (0000001-1 számú főalappont) balti magasságát fogadták el. Mondhatjuk tehát, hogy Magyarországon a Nadap községben lévô, fizikailag létezô két fôalappont ôrzi a magassági alapszintet; továbbra is minden magasság az ôsponthoz viszonyított.

A nadapi szintezési ôspont feletti dombon 1991-ben egy ún. lépcsôs GPS-pontot is létesítettek. Ez a magyar GPS-hálózat (OGPSH) keretpontja, pontszáma 54-2050, magasságát az EOMA-ban nagy pontossággal mérték meg.

Ezt a különleges helyszínt (ami egyediségénél és szakmatörténeti jelentôségénél fogva kiemelt érték) választottuk felmérésünk tárgyául; oktatási céllal, kulturális örökségvédelmi céllal, valamint két, pontfelhőalapú, újszerú technológia összehasonlítása végett.

A pontfelhőalapú adatgyújtés (nevezetesen a lézerszkenneres és az UAV-os felmérés) egy ilyen történelmi helyszínen is kiválóan használható, mind részletesség, mind pontosság tekintetében kielégítô eredményt adhat. Olyan bonyolult természetes alakzatokat, mint például egy sziklafal, hagyományos geodéziai módszerekkel lehetetlen kimagasló részletességgel térképezni. A különleges helyszínen a két technológia különbségeit kívánjuk bemutatni, kifejezetten átlagos munkavégzési módszert használva.

Piaci tevékenység esetén egy adott munka elvégzése előtt fontos tájékozódnunk, hogy milyen minôségben fogják hasznosítani a termékünket, többnyire szükséges a geodéziai minôsítés is. A tervezési térkép készítésének szabályait az MMK Tervdokumentációk tartalmi és formai követelményei szabályzat, valamint az M2 tervezési segédlet említi, amely elérhetố a kamara honlapján, bár éppen az új technológiákkal kevéssé foglalkozik. (Siki-Holéczy, 2018)

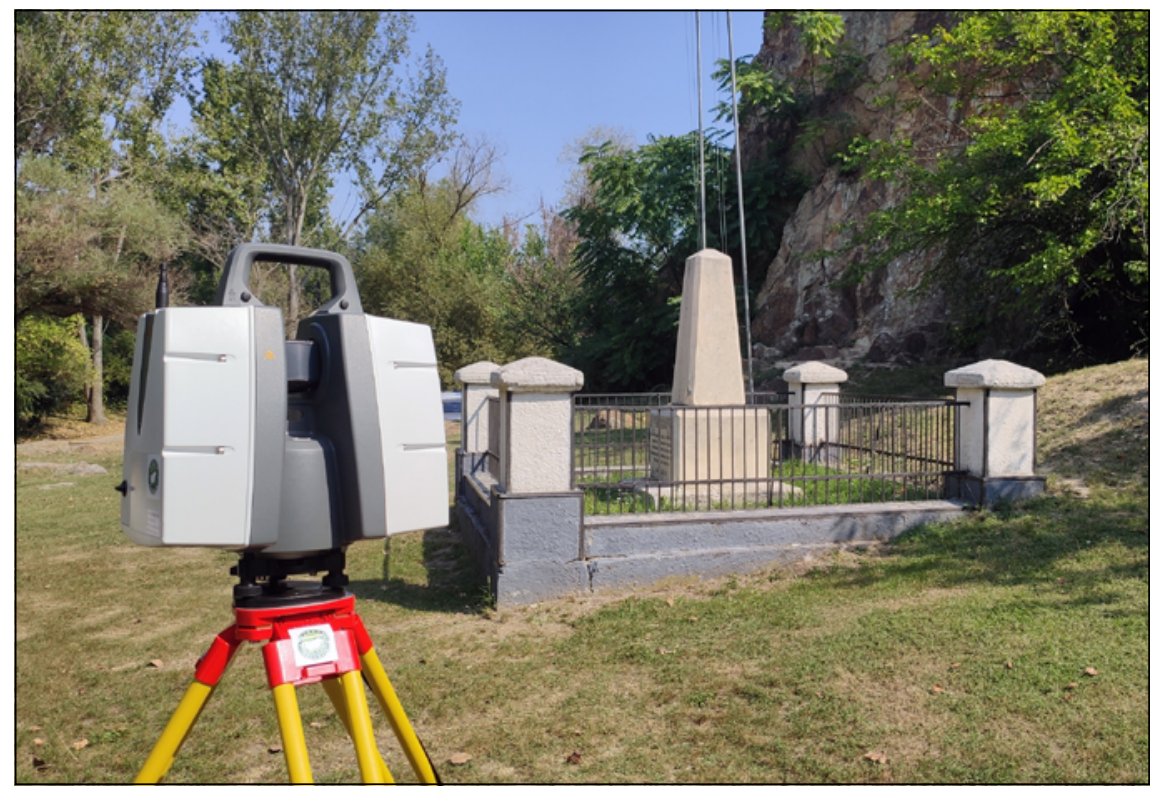

2. ábra. Leica P40 lézerszkenner az obeliszk elôterében

\section{Földi lézerszkenneres felmérés}

A földi felmérést Leica P40 típusú lézerszkennerrel végeztük. A megfelelố álláspontsúrúséget minden esetben a terep összetettsége, tagoltsága határozza meg. Mérôállomással, hasonló körülmények között végrehajtott felmérés során, a munka egy-egy múszerállásban 15-20 percig is eltarthat. Ezzel szemben egy korszerú statikus lézerszkennerrel (az angol szaknyelvben elterjedt nevén Terrestrial Laser Scanner - TLS) napjainkban ennyi idố alatt - ahogy a felmérés során is alkalmaztuk - több millió pontot tudunk hasonló pontossággal meghatározni.

A terepbejárás és méréstervezés folyamata után az elôre kijelölt 8 különbözó álláspontból próbáltuk meg a szintezési ósjegy és a sziklafal környékét kielégítô részletességgel felmérni.

Számos tényező befolyásolja lézerszkenneres méréseink pontosságát, leginkább a múszer-specifikációk nem megfelelô ismeretéból fakadó felhasználói hibák (ezért van komoly szerepe a betanulásnak/betanításnak). Számos hibát okozhat a túl heterogén topográfia is. Hibaforrás lehet a vizsgált objektum felületi visszaverôdési tényezője, valamint az illesztôpontok koordinátáinak gyenge pontossága. A szkennerrel végzett mérés gyári

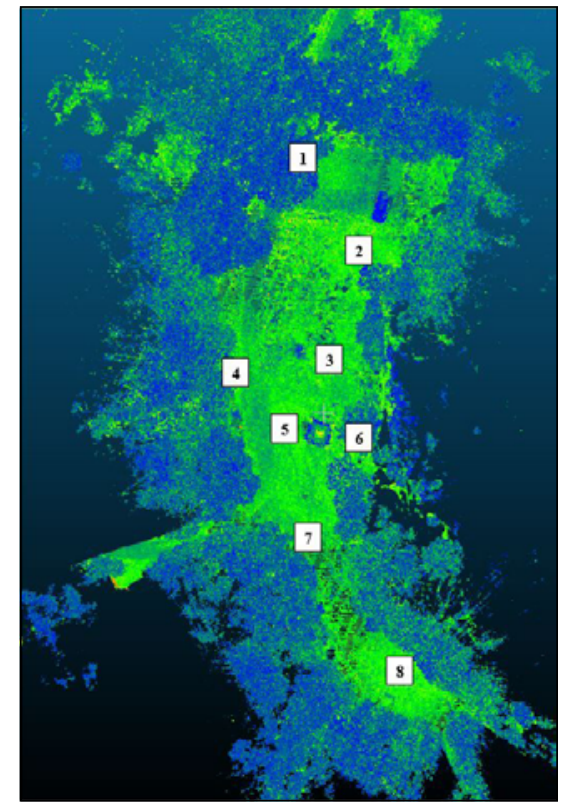

3. ábra. Lézerszkenner-álláspontok

pontossága így jellemezhetô: távmérésre: $1,2 \mathrm{~mm}+10 \mathrm{ppm}$; vízszintes és magassági szögmérésre: 8 másodperc; térbeli ponthibára: 50 méteren $3 \mathrm{~mm}$ és 100 méteren $6 \mathrm{~mm}$.

A pontsûrúségi beállítás $6 \mathrm{~mm}$-es pontköz volt $10 \mathrm{~m}$ távolság esetében. Az átlagos pontköz (beállításoktól függôen) azt jelenti, hogy a lézersugárra merôleges felületen egy $6 \times 6 \mathrm{~mm}$-es négyzet képződik le. A felület egyenetlensége, valamint más beesési szög esetén a pontsûrúség jelentôsen változhat. A részletesség és a szkennelési távolság beállítása fontos paraméter, mert alapvetôen ettôl függ a mérés idôtartama. 
A különbözố szkennelt állományok összeillesztéséhez nem használtunk jeltárcsákat, hanem pontfelhők közötti illesztést végeztünk, ezzel is gyorsítva a mérési folyamatot. A jelenlegi fejlett szoftverháttérnek köszönhetóen ez akár néhány mm-es pontossággal kivitelezhetô. Ehhez természetesen megfelelố átfedésre van szükség az egyes álláspontok pontfelhői között, valamint jól azonosítható, lehetôleg szabályos élekkel, felületekkel rendelkező felmért objektumokra. A konkrét esetben mesterséges objektumok voltak leginkább a segítségünkre.

A mérés nagyjából fél munkanapot vett igénybe, álláspontonként megközelítooleg 15 percet. Ugyan a szkennelés ideje beállítástól függóen csak néhány perc, a fényképezés ideje ennél ötször hosszabb. A létrejött állomány 180 millió pontot tartalmazott.

A feldolgozáshoz a Leica Cyclone szoftverét használtuk, valamint az Autodesk Civil 3D-t és a Cloudcompare-t. Amennyiben nincs vektorizálási feladat, akkor a feldolgozás a terepi munkánál lényegesen rövidebb idôt vesz igénybe. Az egyes álláspontok mérési állományainak számítógépbe importálása után ezek egymáshoz igazítása (a pontfelhốrészek összeillesztése és egységes állománynyá alakítása) dinamikusan végezhetô. Ez az ún. regisztráció folyamata. Elôször javasolt a durva igazítás elvégzése vizuális módszerrel, melyet vízszintes és magassági értelemben is körültekintően kell egymásra igazítani. Érdemes egy vizuális ellenôrzést végezni a modelltérben a véglegesítés elôtt.

Georeferáláshoz (vagyis a helyi rendszerú pontfelhố geodéziai rendszerbe való illesztéséhez) csak a minimálisan szükséges három darab illesztôpontot használtuk, melyek EOV koordinátáit és balti magasságát RTK GNSS-vevôvel határoztuk meg. Illesztôpontnak olyan meglévô természetes objektumokat választottunk ki, melyek nagy bizonyossággal, néhány mm-es pontossággal azonosíthatóak.

Nagyobb munkaterületek esetén javasolt a pontfelhô ritkítása egy megfelelô újra-mintavételezési méret szerint. Ezzel biztosítjuk a homogén eloszlást, valamint a kezelhetôséget. Sok esetben (például építészeti kiértékelés során) a ritkítás vektorizálási pontatlanságot okoz, ezért óvatosan kell bánni vele. Ebben az esetben célszerúbb a pontfelhốt kisebb darabokra osztani a kiértékeléshez. Erre két fố megoldás létezik:

1. A pontfelhôt osztjuk több részre kivágással, ebben kiértékelünk, majd egyesítjük a vektorizált állományokat.

2. Egy doboz használatával az éppen feldolgozott részt jelenítjük meg, a többit elrejtjük. Ezáltal a számítási, megjelenítési erôforrás-szükségletet minimalizáljuk.

Végül megemlítjük, hogy hasonló feladat mobil térképezô rendszerrel (kézi, hátizsákos vagy légi platformmal) is megoldható, a statikus mérés időtartamához viszonyítva gyorsabban, ám valamivel kisebb pontossággal és megbízhatósággal. A mobil térképező eszközök egy kategóriával drágábbak, tekintettel kis méretükre és hordozhatóságukra.

\section{UAV-felmérés}

A kiválasztott quadkopter, a DJI Phantom 4 Pro, 2019-ben a legelterjedtebb fotogrammetriai célra használt UAV-eszköz volt a világpiacon. Térhódítását olcsó árának és megfelelô minôségének köszönheti. Egy átlagos tervezési térképszintû munkára, kis területen, gondos odafigyeléssel, megfelelô minôségú terméket tudunk szolgáltatni.

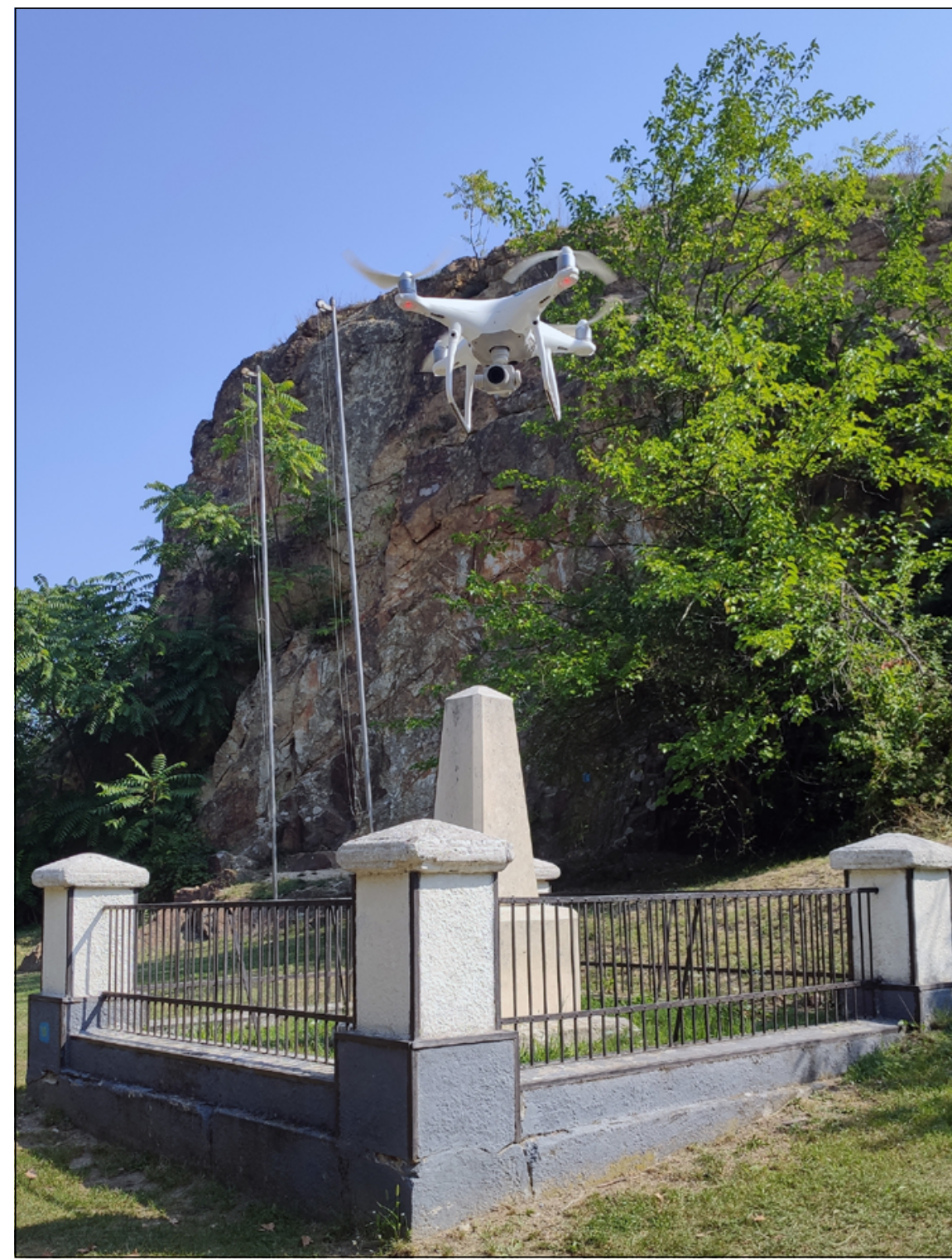

4. ábra. A DJI Phantom 4 Pro az obeliszk fölött 
Az UAV-alapú fotogrammetriai mérések pontossága több tényezôtôl függ. Legfontosabb az illesztőpontok darabszáma, eloszlása és a koordinátáik pontossága. A fotogrammetria szabályainak elvben megfelelő raszterszerú eloszlás valós körülmények között rendszerint nehezen kivitelezhetô, ennek ellenére törekedni kell rá.

Az illesztôpontok kiválasztásánál és eloszlásánál figyelembe kell venni a terület sajátosságait is; a nagy magasságkülönbségekhez, az éles letörésekhez alkalmazkodni kell. Szintén nem hagyható figyelmen kívül az a tény, hogy a felmérendố területet az illesztôpontok közrefogják, mert a kívül esố résznél az extrapoláció bizonytalanságával és negatív hatásával kell számolni (ezt érdemes a múszaki leírásban jelezni). (Balázsik et al. 2016)

Fontos tisztában lennünk az UAVeszköz jellemzôivel is. Felszereltségtől függóen ismerni kell a kamerát, az inerciális mérôegységet (IMU), a GNSS-vevôt és az IMU-GNSS-kamera idôzítési szinkronizálását és a helymeghatározó kalibrálást (Zang 2019). Felméréskor a szkenneléshez képest nagyobb területet jelöltünk ki. Ez plasztikus megjelenítést biztosít a későbbi oktatási, bemutatási feladatokhoz, valamint a mobil felvételi rendszer hatékonyságát is jól demonstrálja. Illesztôpontnak 8 db jeltárcsát helyeztünk ki, a nehéz terepviszonyok

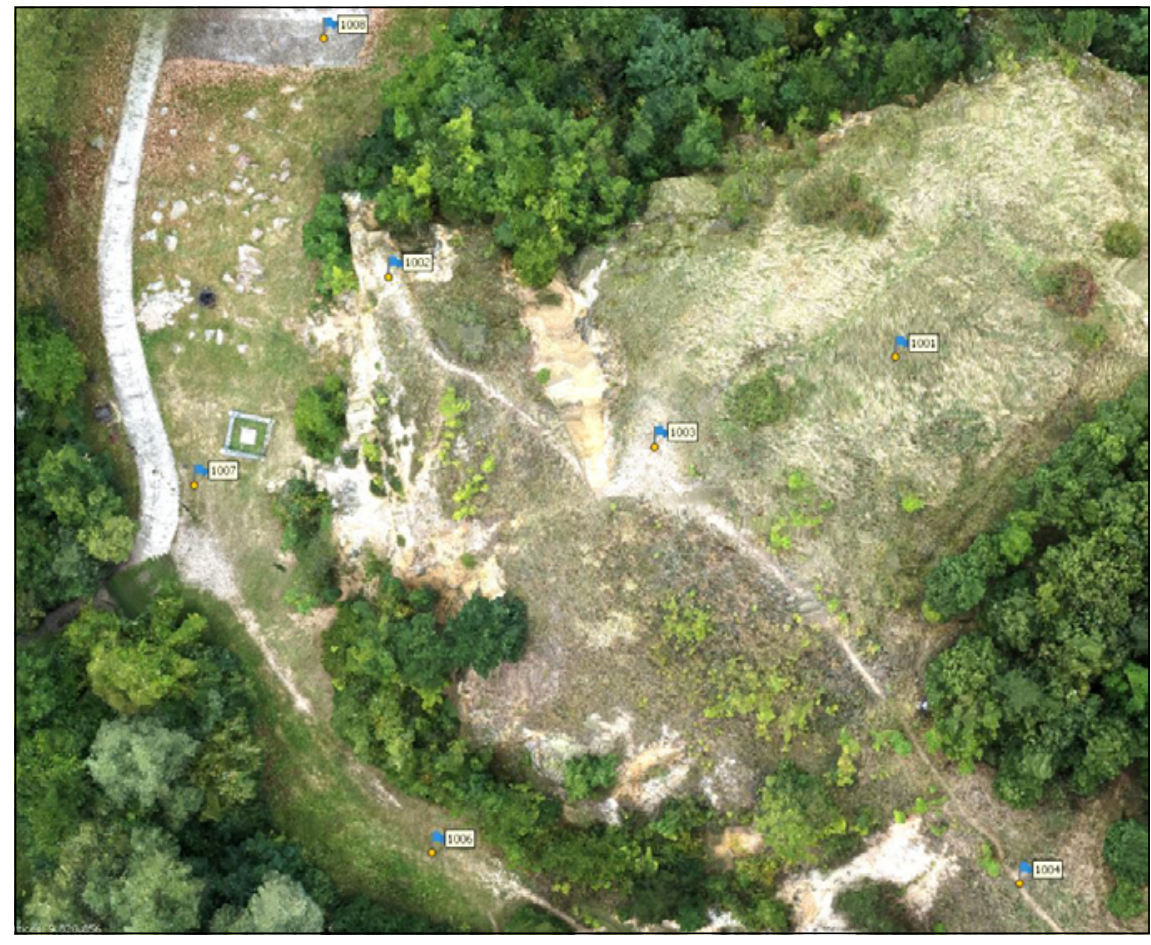

5. ábra. UAV illesztôpontok a sziklafal megközelithetố részein miatt, véletlenszerú eloszlásban. A pontok bemérése ebben az esetben is GNSS-eszközzel, hálózatos RTKval történt. A szkenneléshez használt alappontokat természetesen nem vontuk be a fotogrammetriai számítási munkafolyamatokba.

A repüléstervezés során a 3D Survey szoftverét használtuk. A helyszínen kijelöltük a fényképezni kívánt poligon területét, majd $80 \%$-os átfedéssel, $4 \mathrm{~m} / \mathrm{s}$ sebességgel, a sziklafalra lehetőleg meróleges irányban terveztük a repülés nyomvonalát. A mérés eredményét befolyásolja a repülési útvonal, a repülési magasság, a fotók száma, az átfedés aránya és a felvételezés iránya (nadír vagy oblique, azaz ferde tengelyú). A vizsgálati terület esetében a topográfiai jellemzók, a szél, a fényviszonyok és a színkontraszt is fontos változók. A sebesség és a rezgés elmosódó hatást okozhat a fotón, ezt mindenképpen az előző paraméterekhez képest kell beállítani. Ezért elengedhetetlen ismernünk az alapvetố fotográfiai elemeket, elsôsorban a fényképezés „szentháromságát”, ezek a fényérzékenység, a rekesz és a záridő. A repülés ezen beállítások mellett összesen 6 percet vett igénybe, mely alatt 200 fénykép készült, esetünkben kizárólag nadírfelvételek.

Döntött kamerás felvételek jelen esetben nem készültek, mert ez az általános eset. Azonban, ha egy épülethomlokzat, vagy az esetünkben szereplő sziklafal pontos felmérése lenne a cél, akkor érdemes oblique-felvételeket is készíteni a helyszínen. Ezt a terepi lehetôségek általában nem engedik autonóm módban, így szükséges alapos

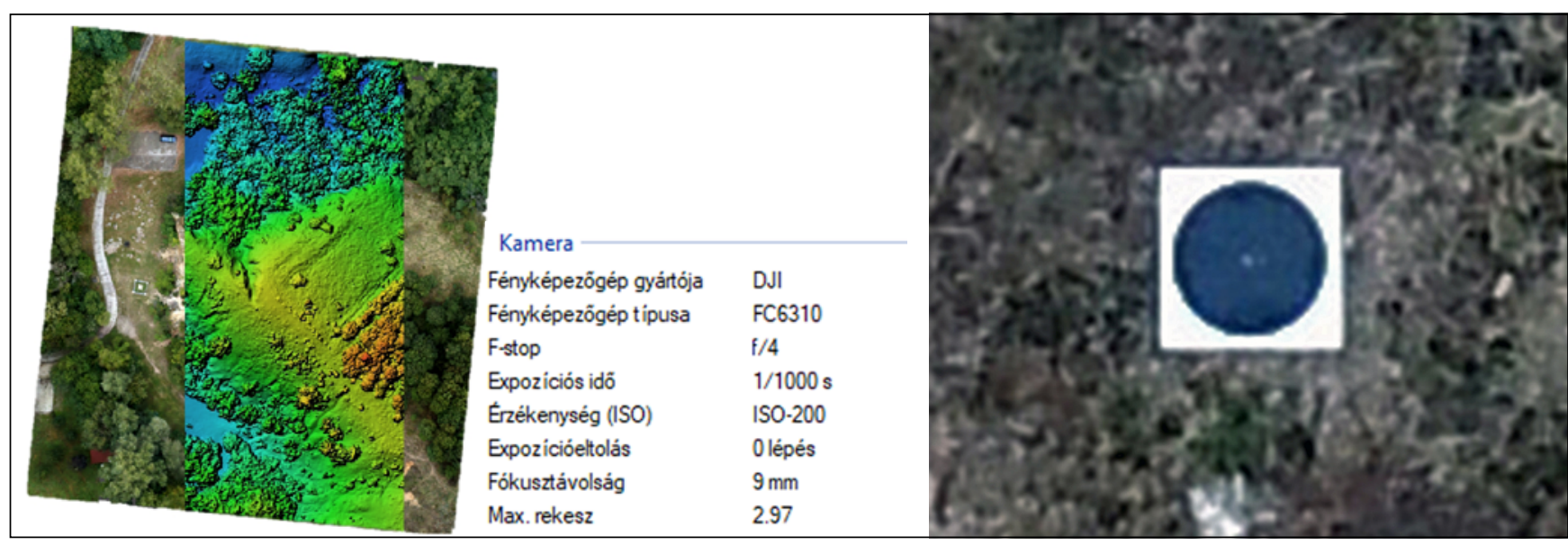

6. ábra. Ortofotó és felszínmodell kombinációja, fényképezési adatok, illesztôpont a légi fotón. 
gyakorlati ismereteket szerezni a manuális repülés és felvételezés szabályairól. A Phantom 4 Pro - profi felszerelésekhez képest gyenge minôségú - kamerájának (FC 330) egyik nagy elônye a Global Shutter használata, amivel a képvándorlás mértékén tudunk csökkenteni, bár a hagyományos Rolling Shutter mozgás közbeni hibájának kompenzálására ma már a legtöbb feldolgozószoftver bizonyos mértékig képes.

Számottevố fotogrammetriai hiba kiküszöböléséhez szükséges a megfelelô szoftveres algoritmus használata (SFM, MVS). A kiértékelést Agisoft Metashape-ben végeztük. A lézerszkenneléssel szemben a fotogrammetria legnagyobb hátránya a pontfelhô előállításához szükséges hosszú idô. Míg a szkennelés során ahogy korábban említettük - szinte azonnal kész pontfelhôhöz jutunk, a fényképalapú vagy videoalapú felmérések során komoly SFM-alapú számítási feladatokat kell alkalmaznunk. Magas beállítási fokozaton, egy középkategóriás munkaállomáson is több óra a feldolgozás munkaideje. Természetesen ehhez nem szükséges az asztal mellett ülnünk, a folyamat $90 \%$-a automatizálható. Viszont így is előrelátó tervezést igényel a kiértékelés idôbeosztása.

\section{Összehasonlító}

\section{eredmények, a mérési állományok egyesítése}

Az ellenôrzés során ismételten bebizonyosodott, hogy a pontfelhóalapú mérési technológiák a tervezési térkép készítéséhez szükséges minőségbeli követelményeket kielégítik. A statikus szkenner pontossági eredményeit már számos tanulmány ismertette, ezért ezt nem részleteznénk. A szúkebb keresztmetszetet a mozgó platformú felméróberendezések jelentik.

A drón pontosságának ellenôrzése során felhasználtuk az 54-2050 számú
OGPSH pontot is, mely jól azonosítható a pontfelhôben. Az eltérés vízszintes értelemben $1 \mathrm{~cm}$, magassági értelemben $2 \mathrm{~cm}$ volt. A munkaterület további RTK ellenôrzó pontjain vízszintesen $1-3 \mathrm{~cm}$, magassági értelemben 3-6 cm-es eltéréseket tapasztaltunk. Ez számos esetben kielégíti a geodéziai pontossági igényeket.

Milyen eltéréseket érdemes dokumentálni egy múszaki leírásban, illetve mire kell odafigyelni?

- Az eltérések abszolút értékeinek átlaga

- A legnagyobb előforduló eltérés

- Az eltérések középhibája

- Ellenôrzőpontok elhelyezésének, bemérésének szabályai:

- A munkaterület mérete, elhelyezkedése

- Az ellenôrzôpontok száma

- Az ellenôrzoópontok súrúsége, eloszlása

- Véletlenszerúen kiválasztott, jól azonosítható legyen.

- A feldolgozó szoftvernek ne adjuk meg ezeket.

- Külsô szoftverben ellenôrizzük.

- Az ellenôrzốpontok bemérésének módja, megbízhatósága

- Mérési bizonytalansággal és a transzformációs hibákkal számolni kell! (Deák-Lehoczky 2019)

Az ellenôrzések számításához kiváló segítséget nyújt a Légi Térképészeti és Távérzékelési Egyesület szakmai ajánlása, amely nemzetközi szabványok alapján került kidolgozásra. (BakóRépás-Lehoczky 2019) Elérhetô az alábbi weboldalon: https://acrsa.org/ hu/index.php/mennyire-pontos

A TLS- és UAV-mérésból származó pontfelhôk összehasonlítása során kiválasztottunk néhány egyértelmúen azonosítható pontot, majd ezek koordinátáit vetettük össze az 1 . táblázatban.

A további felhasználás céljából szükséges volt egyesíteni a TLS- és
UAV-állományt. Az ilyen transzformációs (regisztrációs) módszereket általában két kategóriába sorolhatjuk: durva vagy finom regisztráció. A durva regisztráció egy megfelelố kiindulási értéket biztosít a finom regisztráció részére. Mivel a két pontfelhô már elôzetesen georeferálva lett, erre jelen esetben nem volt szükség. A legnépszerúbb finom regisztrációs módszer az ICP- (Iterative Closest Point/ iteratív legközelebbi pont) algoritmus és ennek változatai. A megfeleltetések közötti négyzetes hibák minimalizálásával optimalizálja a két pontfelhố közötti transzformációt. Pontfelhőpárokra alkalmazva, referenciaállomány kiválasztásával a pontok, normálisok, színek és intenzitásértékek segítségével minimalizálhatjuk az állományok közötti eltérést. Az ehhez hasonló számos regisztrációs folyamat többsége - beépítve -megtalálható a nyílt forráskódú és kereskedelmi szoftverekben. (Zang 2019)

A pontfelhôk egyesítéséhez a CloudCompare nevú ingyenes szoftvert használtuk. Az egyesítés sikerességéhez jelentôs átfedés szükséges a két felhố között. A folyamat során viszszajelzést kapunk a felhô-felhô közötti eltérések mértékérôl. Esetünkben a szkennelt állományt vettük referenciának, és ehhez igazítottuk a kissé pontatlanabb fotogrammetriai munkarészt egy transzformációval.

Legnagyobb problémát a mozgó objektumok, illetve szél esetén a vegetáció mozgása okozza. Fotogrammetriai felmérés során, tekintettel a gyengébb minôségú kamerára és a távolságra, szoftveres félreazonosítás miatt hibás pontok keletkeztek az állományban. Az egyesítési folyamat során nehézséget és pontatlanságot okoztak ezek az egyedileg keletkezett zajok, melyeket néhány szúrési folyamattal tisztítottunk meg. Elsôsorban a Statistical Outlier Filtert hívtuk segítségül, ahol a

1. táblázat Összehasonlító mérések a két pontfelhô azonos pontjai között

\begin{tabular}{|l|l|l|l|l|l|l|l|l|l|}
\hline Psz & Y (TLS) & Y (UAV) & Dif & X (TLS) & X (UAV) & Dif & H (TLS) & H (UAV) & Dif \\
\hline 1 & 617565,86 & 617565,88 & $-0,03$ & 212458,82 & 212458,80 & 0,02 & 176,20 & 176,15 & 0,05 \\
\hline 2 & 617553,66 & 617553,67 & $-0,01$ & 212495,69 & 212495,67 & 0,02 & 175,18 & 175,12 & 0,06 \\
\hline 3 & 617562,85 & 617562,88 & $-0,03$ & 212489,03 & 212489,05 & $-0,02$ & 180,43 & 180,46 & $-0,04$ \\
\hline 4 & 617553,08 & 617553,07 & 0,01 & 212510,56 & 212510,52 & 0,04 & 173,39 & 173,33 & 0,06 \\
\hline 5 & 617553,64 & 617553,61 & 0,03 & 212523,33 & 212523,29 & 0,04 & 172,06 & 172,04 & 0,03 \\
\hline 6 & 617541,42 & 617541,41 & 0,01 & 212497,65 & 212497,63 & 0,02 & 173,30 & 173,30 & 0,00 \\
\hline
\end{tabular}


2. táblázat A kétféle technológia összehasonlítása

\begin{tabular}{|l|l|l|}
\hline & TLS & UAV \\
\hline Idôráfordítás & Több órás terepi munkavégzés & Félórás terepi munkavégzés \\
\hline Feldolgozás & $\begin{array}{l}\text { Azonnali kész pontfelhő, a regisztrálás fél óra } \\
\text { latt elvégezhető. }\end{array}$ & $\begin{array}{l}\text { Hardvertól függóen 2-6 órás feldolgozás, magas } \\
\text { számítási igény. }\end{array}$ \\
\hline Pontsúrúség & $\begin{array}{l}\text { Sûrúbb, de nem homogén eloszlású. } \\
\text { A kivágott vizsgált területen 180 millió pont. }\end{array}$ & $\begin{array}{l}\text { Ritkább, de kvázi homogén eloszlású. } \\
\text { A kivágott vizsgált területen 50 millió pont. }\end{array}$ \\
\hline Színhelyesség & $\begin{array}{l}\text { Az intenzitásérték többlet- információ, viszont } \\
\text { RGB-színek általában gyengébb minőségúek, } \\
\text { nem azonos értéket vesznek fel. }\end{array}$ & $\begin{array}{l}\text { Intenzitás nincs, RGB egyenletes, valós színes, } \\
\text { plasztikus megjelenésú, } \\
\text { ortofotó-elóállítási lehetóség! }\end{array}$ \\
\hline Pontosság & $1-3$ cm jeltárcsák nélkül & 3-6 cm nadírfelvételekből \\
\hline
\end{tabular}

szabályos és véletlen zajokat is sikerült nagy százalékban kiszúrni.

SOR filter:

- $A_{x}=$ szomszédos pontok távolságának átlaga; megj.: (a figyelembe vett szomszédos pontok száma paraméterezhetô)

- nSigma = szórási arányszám

- $\mathrm{D}_{\mathrm{x}}=$ környezô pontok távolságának szórása

- $\mathrm{d}_{\mathrm{z}}=$ teljes adatsor távolsági arányszáma

- $\mathrm{d}_{\mathrm{x}}=\mathrm{X}$ pont távolsági arányszáma

- $d_{\mathrm{z}}=\left[\left(A_{\mathrm{x}}+\left(n\right.\right.\right.$ Sigma $\left.\left.\times D_{\mathrm{x}}\right)\right)+$

$+\left(A_{\mathrm{Y}}+\left(\right.\right.$ nSigma $\left.\left.\times D_{\mathrm{Y}}\right)\right)+\ldots$

$\ldots+\left(A_{\mathrm{n}}+\left(n\right.\right.$ Sigma $\left.\left.\left.\times D_{\mathrm{n}}\right)\right)\right] / \mathrm{n}$

- X zaj, ha d $>$ > d (Yurtseven 2019)

A visszamaradt hibás pontcsoportokat octree-k alapján klasszifikáltuk. (octree: olyan 3D-s fa adattárolási struktúra, ahol a teret rekurzív módon egyenlố méretû kockákra osztjuk, majd azokat további $2 \times 4$ kockára osztva képezzük le.) Connected Components nevú elemzési lehetôséggel kiszúrtük azokat az octree-csoportokat, melyekben a leginkább illeszkedô „n” számú létezó octree volt megtalálható.

Komoly problémát okozott a két állomány színkódjainak eltérése is. Ehhez félautomata és manuális színkorrigálási lehetôségeket használtunk, esetleg fotogrammetriai szoftverbe importálva fényképek alapján történó újraszínezést alkalmazhatunk.

A fó nehézség a különbözô platformokból származó pontfelhôsứrúségben tapasztalható eltérés volt. Ugyan a vizuális ellenőrzés alapján megállapíthattuk, hogy a sziklafal területei közötti regisztráció megfelelôen illeszkedik, bonyolult alakzatok megfelelô pontosságú fúziójának eléréséhez további számítási technikák kidolgozása szükséges, optimalizálni kell a kényszerparaméterek meghatározásának módszerét. Egyszerúsíteni kell a párosítás, súlyozás, szelektálás folyamatát megfelelô mértékű véletlenszerú válogatással, hogy a normálisok eloszlása minél egyenletesebb legyen.

\section{Összefoglalás}

Egy szakmatörténeti szempontból kiemelkedô helyszín, a nadapi szintezési ősjegy és terepi környezetének részletes felmérését végeztük el földi lézerszkenner és UAV alkalmazásával. E két korszerú adatgyújtési technológiával még átlagos használat során is jól láthatóan elkülöníthetôk, osztályozhatók, interpretálhatók a fontos környezeti, geológiai és építészeti elemek. A topográfia miatti és a lejtési viszonyokból eredố hibák kis mértékben, de kimutathatóak. További vizsgálatok szükségesek ahhoz, hogy a repülési irány milyen mértékben befolyásolja a végtermék pontosságát.

Ez a teszt is bizonyította, hogy a modern felmérési technológiáknak helye van a földmérôszakmában, megbízhatóságuk a ma már rutinnak számító megoldások mellett is kielégítő lehet, ám a kiértékelési folyamatok során mindig megfelelốn kell figyelembe venni, milyen módszerrel és megbízhatósággal készült az adott állomány. (Bakó-Répás-Lehoczky 2019) Fontosnak tartjuk, hogy ezen technológiák használata és alkalmazása megfelelố szerepet kapjon a szakmai oktatásban és továbbképzésben. Használatukat és szabályozásukat a kataszteri munkavégzésben is érdemes lenne felülvizsgálni.

\section{Irodalom}

Bakó Gábor - Répás Zoltán - Lehoczky Máté 2019. A Légi Térképészeti és Távérzékelési Egyesület ajánlása a légi távérzékeléssel gyújtött téradatok síkrajzi pontosságának elemzéséhez. Az elmélet és a gyakorlat találkozása a térinformatikában X. térinformatikai konferencia, Debrecen. http:// giskonferencia.unideb.hu/arch/GIS Konf kotet 2019.pdf

Balázsik Valéria - Busics György - Engler Péter - Farkas Róbert - Földváry Lóránt - Jancsó Tamás - Kiss Attila - Tóth Zoltán - Verôné Wojtaszek Malgorzata 2016. Tesztmezố kialakítása az Iszka-hegyen és UAV-ok pontosság vizsgálatának elsố eredményei, Remote Sens. 6 (3), pp. 448-454

Busics György 2013. Adalékok a nadapi szintezési főalappontok történeté hez. NymE GEO, Székesfehérvár. p. 81 ISBN 978-963-359-010-2

Deák Márton - Lehoczky Máté 2019. Drónok, kalibrálás, pontfelhố feldolgozás, MMKGGT továbbképzési tananyag, https:// www.mmk.hu/szolgaltatasok/tovabbkepzes/ tananyagok

Siki Zoltán - Holéczy Ernô 2018. Kell egy geodézia! Mérnök Újság XXV. évf. 10. szám

Yurtseven, Huseyin 2019. Comparison of GNSS-, TLS- and Different Altitude UAVGenerated Datasets on The Basis of Spatial Differences, ISPRS Int. J. Geo-Inf., 8, p. 175 DOI: $10.3390 /$ ijgi8040175

Zang, Yufu -Yang, Bisheng - Li, Jianping Guan, Haiyan 2019. An Accurate TLS and UAV Image Point Clouds Registration Method for Deformation Detection of Chaotic Hillside Areas, Remote Sens. DOI: $\underline{10.3390 / \mathrm{rs} 11060647}$

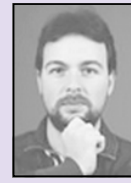

Lehoczky Máté földmérômérnök

Pannon Geodézia Kft. lehoczky@pannongeodezia.hu

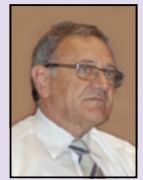

Dr. Busics

György

c. egyetemi tanár

Óbudai Egyetem Alba Regia

Mû́szaki Kar

busicsgy@gmail.com 